Vol. 9(35), pp. 1974-1977, 2 September, 2015

DOI: 10.5897/AJMR2015.7629

Article Number: 103450855541

ISSN 1996-0808

Copyright (C) 2015

African Journal of Microbiology Research

Author(s) retain the copyright of this article

http://www.academicjournals.org/AJMR

\title{
Seroprevalence of Ehrlichia canis in dogs from Monterrey, Mexico
}

\author{
Salinas-Meléndez, J. A., Cantú-Martínez, M.A., Wong-González, A., Hernández-Escareño, J. J., \\ Ávalos-Ramírez, R., Zárate-Ramos, J. J. and Riojas-Valdés, V. M. *
}

Universidad Autónoma de Nuevo León, Facultad de Medicina Veterinaria y Zootecnia. Av. Universidad S/N, Ciudad universitaria, San Nicolás de los Garza, Nuevo León. C.P. 66451, México.

Received 17 June, 2015; Accepted 17 August, 2015

\begin{abstract}
Infection by Ehrlichia canis in dogs causes the worldwide tick-borne disease called canine monocytic ehrlichiosis (CME), and the presence of $E$. canis has been serologically demonstrated in all continents, with prevalence ranging from 0.2 to $80 \%$. In southern Mexico, a prevalence of $44 \%$ was found, whereas in the northwest part of the country it varies from 21 to $49 \%$. In the present study, a commercial kit for the detection of antibodies against $E$. canis was used in 391 dogs from the city of Monterrey, which is located at northeast of Mexico. A total of 54 samples were positive, giving a prevalence of $13 \%$. According to sex, prevalence was $14 \%$ for males and $13 \%$ for females. Positive animals varied in age from 21 to 132 months old and only 10 of them presented ticks. As in the southern and northwest parts of Mexico, CME is present in northeast region, although with a lower prevalence.
\end{abstract}

Key words: Ehrlichia canis, dogs, serology, Mexico.

\section{INTRODUCTION}

The dog can be infected by different species of Ehrlichia, and Ehrlichia canis is the most important species; it is transmitted by Rhipicephalus sanguineus (Pusterla et al., 1998), although the American dog tick, Dermacentor variabilis, has also been shown to be a vector transmitter of this disease (Johnson et al., 1998).

$E$. canis is the primary causal agent of Canine Monocytic Ehrlichiosis (CME), a worldwide tick-borne disease (Kamani et al., 2013; Stich et al., 2008); it is an obligate intracellular gram-negative bacterium that multiply in eukaryotic cells, like monocytes and macrophages, developing leucopenia and thrombocytopenia
(Stich et al. 2008).

CME can be divided in an acute phase, beginning from 8 to 20 days after infection, involving anemia, anorexia, ataxia, conjunctivitis, depression, fever, leucopenia, ocular discharge, thrombocytopenia and vomiting that end with a partial recovery of the dog, followed by an months-to-years subclinical phase. The chronic phase can be mild or severe with recurrent clinical and hematologic signs like pancytopenia, hemorrhage, monocytosis, lynphocytosis and weight loss (Stich et al., 2008). It is thought that $E$. canis is the only agent responsible for the development of $\mathrm{CME}$. It has been

*Corresponding author. E-mail: vriojas@hotmail.com. Tel: (81) 1340-4390, ext. 3616.

Author(s) agree that this article remains permanently open access under the terms of the Creative Commons Attribution License 4.0 International License 
suggested that this bacteria could be the causal agent in the human granulicytic ehrlichiosis and it has even been successfully isolated from human patients with symptoms similar to those caused by other infections by $E$. chafeensis and E. ewingii (Perez et al., 2006; Nicholson et al., 2010).

Serologic evidence of previous studies around the world indicated that $E$. canis is present among dogs throughout all continents, where serologic studies have found a prevalence ranging from 30 to $80 \%$ in some countries of Africa (Azzag et al., 2015; Inokuma et al., 2006; Eoghain and Raoult, 2004; Ndip et al., 2005; Davoust et al., 2006), whereas in some Asian countries it was of 0.2 to $30 \%$ (Inokuma et al., 1999; Rajamanickam et al., 1985; Stich et al., 2008).

In Europe, a prevalence ranging from 2 to $50 \%$ have been found (Solano-Gallego et al., 2006; Cocco et al., 2003; Pusterla et al., 1998; Sainz et al., 1995). A study realized in the USA detected most often Ehrlichia antibodies in dogs in the Southeast, with $1.3 \%$ of samples testing positive, whereas other regions showed lower numbers ranging from 0.3 to $0.6 \%$. (Bowman et al., 2009). Different results were found in Oklahoma, where the prevalence of $E$. canis was $10.8 \%$ by serology and $3.1 \%$ by the polymerase chain reaction (PCR) method (Murphy et al., 1998). Among dogs belonging to the U.S.A. military forces, seropositivity to $E$. canis ranged from $8 \%$ in cold zones (above $45^{\circ}$ latitude) to $24 \%$ in temperate places (between 40 and $45^{\circ}$ latitude); a $13 \%$ prevalence was found in tropical zones (below $40^{\circ}$ latitude) (Keefe et al., 1982).

Several studies on $E$. canis prevalence have been realized in Brazil. Melo et al. (2011) reported a prevalence of $74.4 \%$ in urban and of $67.5 \%$ in rural dogs (overall frequency of $70.9 \%$ ), whereas Witter et al. (2013) informed a seroprevalence of $70.1 \%$; in this last study the frequency of $E$. canis infection was of $23.3 \%$ by PCR. On the other hand, also in Brazil a prevalence of $E$. canis of $41.5 \%$ by IFA and of $9.4 \%$ was found in cats (Braga et al., 2014).

In Grenade, $43.8 \%$ of dogs tested were positive for $E$. canis (Yabsley et al., 2008). In Mexico, studies performed in the southern area found $44 \%$ of seropositive dogs to $E$. canis with ELISA testing (Rodriguez-Vivaz et al., 2005), $36 \%$ prevalence by PCR and $45 \%$ in dogs located at animal shelters (Pat-Nah et al., 2015), whereas at the northwest region a prevalence of $49 \%$ was found (Tinoco-Gracia et al., 2007). In another study (HaroÁlvarez et al., 2007), a $21.6 \%$ prevalence, with $40 \%$ of the dog population in contact with E. canis, have been reported.

Although much have been said about the presence of this disease in Mexico, currently there are no reports of it in the northeast region; therefore, the goal of the present study was to estimate the seroprevalence of ehrlichiosis in dogs from the city of Monterrey, located in this part of Mexico.

\section{MATERIALS AND METHODS}

Blood samples were obtained from 391 dogs of different breeds in the city of Monterrey, using as inclusion factor only animals with fixed address, age over 6 months. It was decided to sample only one animal per house in case of having more than one dog. The examination of the dogs started with physical evaluation followed by blood sampling. All dogs showed no symptoms of any disease.

This study was carried out during 2014 in the city of Monterrey, Nuevo Leon, located in the northeast of Mexico, with a territorial extension of 451.30 square kilometers. Location coordinates are $25^{\circ} 40^{\prime} 17^{\prime \prime} \mathrm{N}, 100^{\circ} 18^{\prime} 31^{\prime \prime} \mathrm{W}$. Altitude is $530 \mathrm{~m}$ above sea level. The climate of the region has an average of $21^{\circ} \mathrm{C}$, but because of annual thermal oscillation of $18^{\circ} \mathrm{C}$, with important contrast among seasons. In summertime, temperatures above $30^{\circ} \mathrm{C}$ are common with an average in July and August of $34^{\circ} \mathrm{C}$. In Winter, cold air arrive constantly to the region, often accompanied of humidity from the coast, making the temperature descend drastically, and every year at least two to three days are recorded with $0^{\circ} \mathrm{C}$ or less. The average annual precipitation is of $600 \mathrm{ml}$ spread mainly in summer, with September as the rainiest month. The city was divided in quadrants in accordance with its cartographic plan. From this map, the 15 most urbanized quadrants were chosen, since the others belonged to non-well developed neighborhoods and little human population. Sampling was performed according to the dog population density and owner cooperation, and only one animal per city block and only one animal per house. To determine the sample size, calculations were made in basis of the population's representative sample (infinite), with precision level of $5 \%$, confidence level of $95 \%$ and a power of statistical test of $80 \%$ in order to ensure reliability of the results and that they could be translated to the population under study. Sample size was determined using Epidat 3.1. For the in vitro diagnosis for detection of antibodies against $E$. canis in the samples, a commercial kit canine SNAP*4Dx (IDEXX labs, Inc. USA) was used. Before starting the procedure, samples must be at room temperature. The sera, either fresh or refrigerated, were utilized after no more than a week from the sampling. Sensitivity and specificity of the kit for the disease are reported with a minimum of $98.8 \%$ and $100 \%$, respectively, and detects antibodies generated against peptides from the proteins p30 and p30-1 of Ehrlichia. (O'Connor et al., 2004, 2006).

\section{RESULTS AND DISCUSSION}

For the present work, 391 blood samples were taken from dogs located in the city of Monterrey, Mexico; antibodies against $E$. canis were found in 54 samples, resulting in a prevalence of $13.8 \%$. Regarding to sex, animal's samples comprised 173 males and 218 females of which 25 males and 29 females were positive, giving a prevalence of 14.5 and $13.3 \%$ respectively (Table 1 ).

Positive animals varied in age from 21 to 132 months old; and according to size, 19 were small, 27 medium and eight large. Only 10 positive animals presented ticks (Rhipicephalus sanguineus). The distribution of positive animals by breed is presented in Table 2; the biggest percentage of positive dogs was for mixed-breed.

Comparing the frequencies found in the present work to other studies on the subject can be difficult due to the wide range of prevalence reported according to the continent in which such studies were performed (from 0.2 to $80 \%$ in Africa, Asia and Europe), as can be seen in the 
Table 1. Distribution of positive animals for Ehrlichia canis by sex.

\begin{tabular}{lccc}
\hline Sex & Number of dogs sampled & Number of positive dogs & $\%$ \\
\hline Female & 218 & 29 & 13.3 \\
Male & 173 & 25 & 14.5 \\
Total & 391 & 54 & 13.8 \\
\hline
\end{tabular}

Table 2. Number of positive animals to Ehrlichia canis according to breed.

\begin{tabular}{lc}
\hline Breed & Number of positive animals \\
\hline Basset Hound & 1 \\
Boxer & 3 \\
Bull Terrier & 3 \\
Chihuahua & 2 \\
Cocker Spaniel & 2 \\
Collie & 1 \\
Mixed breed & 16 \\
Doberman & 1 \\
French poodle & 5 \\
Great Dane & 2 \\
Maltese & 4 \\
Labrador & 4 \\
Schnauzer & 2 \\
German shepherd & 1 \\
Shar Pei & 2 \\
Shih tzu & 4 \\
Westhighland & 1 \\
\hline
\end{tabular}

Introduction section. However, when we compare our work with studies done in the U.S.A., we find that a very similar prevalence (10.8\%) was found in Oklahoma by serology, although in this same paper the prevalence was $3.1 \%$ by PCR (Murphy et al., 1998). This low prevalence of $E$. canis by PCR in the U.S.A. is confirmed by other work that informed $1.3 \%$ in the Southwest and 0.3 to $0.6 \%$ in other areas of that country (Bowman et al., 2009). On the other hand, a very large prevalence of $E$. canis in dogs has been informed in both Grenade (Yabsley et al., 2008) and south Mexico (Rodriguez-Vivaz et al., 2005); in the first, the prevalence was of $43.8 \%$ and in the second of $44 \%$. Other studies in Mexico concluded that the prevalence of $E$. canis is high, ranging from 40 to $49 \%$ in both the northwest and south part of the country (Haro-Álvarez et al., 2007; Pat-Nah et al., 2015; TinocoGracia et al., 2007). These results are in disagreement with the ones presented in our work. Therefore, a wide range of results regarding the prevalence of $E$. canis in dogs exist in the literature. One possible explanation to this disagreement could be the diagnostic method. Work in this subject indicate that the IFA method may be better than ELISA (Jimenez-Coello et al., 2009); using the IFA method these authors found a $8.7 \%$ prevalence, which is closer to the results informed in the present work; the previously mentioned work also indicates that the sampling method can also have an influence in the results. We think that both the sampling method and the technique used in the present study give an accurate view of the actual prevalence of $E$. canis infection in dogs located in the northeast region of Mexico; the prevalence we found is close to the ones reported in the U.S.A. and in the work done by Jimenez-Coello et al. (2009) in Mexico, but much lower to the prevalence informed in both the south and northwest areas of Mexico, as well as in other parts of the world as mentioned above.

\section{Conflict of interests}

The authors did not declare any conflict of interest.

\section{ACKNOWLEDGEMENTS}

We wish to thank the Programa Integral para el Fortalecimiento Institucional (PIFI) program of the Universidad Autónoma de Nuevo León for financial support to this work.

\section{REFERENCES}

Azzag N, Petit E, Gandoin C, Bouillin B, Ghalmi F, Haddad N, Boulois $\mathrm{H}-\mathrm{J}$ (2015). Prevalence of selected vector-borne pathogens in stray and client-owned dogs from Algiers. Comp. Immunol. Microbiol. Infect. Dis. 38:1-7.

Bowman D, Susan EL, Lorentzen L, Shields J, Sullivan MP, Carlin EP (2009). Prevalence and geographic distribution of Dirofilaria immitis, Borrelia burgdorferi, Ehrlichia canis, and Anaplasma phagocytophilum in dogs in the United States: Results of a national clinic-based serologic survey. Vet. Parasitol. 160:138-148.

Braga IA, dos Santos LG, de Souza Ramos DG, Melo AL, da Cruz Mestre GL, de Aguiar DM (2014). Detection of Ehrlichia canis in domestic cats in the central-westwrn region of Brazil. Braz. J. Microbiol. 45:641-645.

Cocco R, Sanna G, Cillara MG, Tola S, Ximenes L, Pinnaparpaglia ML, Masala G (2003). Ehrlichiosis and Rickettsiosis in a canine population of Northern Sardinia. Ann. N.Y. Acad. Sci. 990:126-130.

Davoust B, Boni M, Gomez J, Lafay L, Casali F, Leroy E, Parzy D (2006). Surveys on seroprevalence of canine monocytic Ehrlichiosis among dogs living in the Ivory Coast and Gabon and evaluation of a quick commercial test kit dot-ELISA. Ann. N.Y. Acad. Sci. 1078:464469.

Eoghain GN, Raoult D (2004). Antibodies reactive with Bartonella henselae and Ehrlichia canis in dogs from the communal lands of 
Zimbabwe. J. S. Afr. Vet. Assoc. 75:116-120.

Haro-Alvarez P, Lopez-valencia G, Tinoco-Gracia L, RenteriaEvangelista T, Medina-Basulto G (2007). Seroprevalence and traceback of animals suspected of carrying Ehrlichia canis, in dogs attended in veterinary clinics in Mexicali, Baja California, Mexico. JAVA 6:850-854.

Inokuma H, Ohno K, Yamamoto S (1999). Serosurvey of Ehrlichia canis and Hepatozoon canis infection in dogs in Yamaguchi Prefecture, Japan. J. Vet. Med. Sci. 61:1153-1155.

Inokuma H, Oyamada M, Davoust BM, Boni M, Dedeure J, Bucheton B, Hammad A, Watanabe M, Itamoto K, Okuda M, Brouqui P (2006). Epidemiological survey of Ehrlichia canis and related species infection in dogs in Eastern Sudan. Ann. N.Y. Acad. Sci. 1078: 461 463.

Jimenez-Coello M (2009). Vector Borne Zoonot. Dis. 9:209-211.

Johnson EM, Ewing SA, Barker RW, Fox JC, Kocan KM (1998). Experimental transmission of Ehrlichia canis by Dermacentor variabilis. Vet. Parasitol. 74: 277-288.

Kamani J, Lee CC, Haruna AM, Ping-Jun, Chung P-J, Weka PR, Chung Y-T (2013). First detection and molecular characterization of Ehrlichia canis from dogs in Nigeria. Res. Vet. Sci. 94:27-32.

Keefe TJ, Holland CJ, Salyer PE, Ristic M (1982). Distribution of Ehrlichia canis among military working dogs in the world and selected civilian dogs in the United States. J. Am. Vet. Med. Assoc. 181:236238.

Melo AL, Martins TF, Horta MC, Moraes-Filho J, Pacheco RC, Labruna MB, Aguiar DM (2011). Seroprevalence and risk factors to Ehrlichia spp. and Rickettsia spp in dogs from the Pantanal Region of mato Grosso State, Brazil. Ticks Tick Borne Dis. 2:213-218.

Murphy GL, Ewing SA, Whitworth LC, Fox JC, Kocan AA (1998). A molecular and serologic survey of Ehrlichia canis, E. chaffeensis, and E. ewingii in dogs and ticks from Oklahoma. Vet. Parasitol. 79:325339.

Ndip LM, Ndip RN, Esemu SN, Dickmu VL, Fokam EB, Walker DH, McBride JW (2005). Ehrlichial infection in Cameroonian canines by Eherlichia canis and Ehrlichia ewingii. Vet. Microbiol. 111: 59-66.

Nicholson WL, Allen KE, McQuiston JH, Breitschwerdt EB, Susan EL. (2010). The increasing recognition of rickettsial pathogens in dogs and people. Trends Parasitol. 26:205-212.

O'Connor TP, Esty KJ, Jancy L, Hanscom JL, Shields P, Philipp MT (2004). Dogs vaccinated with common Lyme disease vaccines do not respond to $I_{6}$, the conserved immunodominant region of the VIsE surface protein of Borrelia burgdorferi. Clin. Diagn. Lab. Immunol. 11:458-462

O'Connor TP, Hanscom JL, Hegarty BC, Groat RG, Breitschwerdt EB (2006). Comparison of an indirect immunofluorescence assay, western blot analysis, and a commercially available ELISA for detection of Ehrlichia canis antibodies in canine sera. Am. J. Vet. Res. 67:206-210.
Pat-Nah H, Rodriguez-Vivas RI, Bolio-Gonzalez ME, Villegas-Perez SL, Reyes-Novelo E (2015). Molecular diagnosis of Ehrlichia canis in dogs and ticks Rhipicephalus sanguineus (Acari:Ixodidea) in Yucatan, Mexico. J. Med. Entomol. 52:101-104.

Perez M, Bodor M, Zhang C, Xiong Q, Rikihisa Y (2006). Human infection with Ehrlichia canis accompanied by clinical signs in Venezuela. Ann. N.Y. Acad. Sci. 1078:110-117.

Pusterla N, Pusterla JB, Deplazes P, Wolfensberger C, Muller W, Horauf A, Reusch C, Lutz H (1998). Seroprevalence of Ehrlichia canis and granulocytic Ehrlichia infection in dogs in Switzerland. J. Clin. Microbiol. 36:3460-3462.

Rajamanickam C, Wiesenhutter E, Zin FM, Hammid J (1985). The incidence of canine haematozoa in Peninsular Malaysia. Vet. Parasitol. 17: 151-157.

Rodriguez-Vivaz, RI, Albornoz REF, Bolio GME (2005). Ehrlichia canis in Yucatan, Mexico: seroprevalence, prevalence of infection and associated factors. Vet. Parasitol. 127: 75-79.

Sainz A, Tesouro MA, Rodriguez F, Mayoral I, Mazzucchelli F (1995). Seroprevalence of Ehrlichia canis infections in pólice dogs in Spain. Prev. Vet. Med. 23:179-182.

Solano-Gallego L, Trotta M, Razia L, Furlanello T, Caldin M (2006). Molecular survey of Ehrlichia canis and Anaplasma phagocytophilum from blood of dogs in Italy. Ann. N.Y. Acad. Sci. 1078:515-518.

Stich RW, Shaefer JJ, Bremer WG, Needham GR, Jittapalapong S (2008). Host surveys, ixidid thick biology and transmission scenarios as related to the thick-borne pathogen, Ehrlichia canis. Vet. Parasitol. 158:256-273.

Tinoco-Gracia L, Quiroz-Romero H, Quintero-Martinez T, RenteriaEvangelista TB, Barreras-Serrano A, Hori-Oshima S, Lopez-Valencia G, Tamayo-Sosa AR, Quezada-Iniguez VA, Moro-Manuel VJ (2007). Seroprevalence of Ehrlichia canis in dogs from a mexico-U.S. border desert region: Pilot study. JAVA 6:758-760.

Witter R, Nunes Vecchi S, dos Anjos Pacheco T, Tomé Melo AL, Borsa A, Sinkoc AL, Mendonca AJ, Moura Aguiar D (2013). Prevalencia da erliquiose monocitica canina e anaplasose trombocitica em caes suspeitos de hemoparasitose em Cuiaba, Mato Grosso. Semina: Ciencias Agrarias 34:3811-3822.

Yabsley MJ, McKibben J, Macpherson CN, Cattan PF, Cherry NA, Hegarty BC, Breitschwerdt EB, O`Connor T, Ramaswamy R, Paterson T, Perea ML, Ball G, Friesen S, Goedde J, Henderson B, Sylvester W (2008). Prevalence of Ehrlichia canis, Anaplasma platys, Babesia canis vogeli, Hepatozoon canis, Bartonella vinsoni berkhoffii, and Rickettsia spp. in dogs from Grenada. Vet. Parasitol. 151:279285. 